KINGA MARULEWSKA

Instytut Politologii UMK

\title{
Tradycja klasyczna a kryzys współczesnej polityczności według Hannah Arendt
}

Ponieważ przeszłość nie rzuca już swego światła na przyszłość, rozum ludzki błądzi w ciemnościach

A LEX I S D T O C Q U E V I L L E

Dowrót do filozofii i tradycji klasycznej, jaki dokonał się u wielu myślicieli dwudziestego wieku ${ }^{1}$, był udziałem również Hannah Arendt. Myślicielka ta, wychowana intelektualnie $\mathrm{u}$ boku Martina Heideggera i Karla Jaspersa ${ }^{2}$,

Warto w tym kontekście wspomnieć m.in. o powrocie do arystotelesowskiej koncepcji telos dokonanym przez Alasdaira MacIntyre'a (Por. A. MacIntyre, Dziedzictwo cnoty, przeł. A. Chmielewski, Warszawa 1996; Tenże, Czyja sprawiedliwość? Jaka racjonalność?, przeł. A. Chmielewski i in., Warszawa 2007), powrocie do klasycznej filozofii noetycznej dokonanym przez Erica Voegelina (Por. E. Voegelin, Nowa nauka polityki, przeł. P. Śpiewak, Warszawa 1992) oraz odróżnieniu pomiędzy klasyczną a nowożytną filozofią polityki, przy jednoczesnym opowiedzeniu się za tą pierwszą, jakie możemy dostrzec u Leo Straussa (Por. L. Strauss, Czym jest filozofia polityki? w: Tenże, Sokratejskie pytania, przeł. P. Maciejko, Warszawa 1998, s. 61-106).

W czasie, kiedy Arendt zaczęła studiować w Marburgu (1924), Heidegger zaczynał już swoją błyskotliwą filozoficzną karierę, zwłaszcza wśród młodych ludzi. Nic dziwnego, że Arendt znalazła się na jego seminariach - sława buntownika przeciwko dotychczasowej filozofii przyciągała. Jednakże, aby uwolnić się spod silnego wpływu Heideggera oraz ich długo trzymanego w ukryciu romansu, swój doktorat na temat pojęcia miłości u św. Augustyna pisała już u Karla Jaspersa w Heidelbergu. Por. E. Young-Bruehl, Hannah Arendt. For Love of the Word, New Heaven-London 1982, s. 42-77. 
z wielką swobodą korzystała „z dorobku mistrzów bardzo, wydawałoby się, od siebie odległych"3. Obok nawiązań do Arystotelesa możemy znaleźć i takie do Monteskiusza czy Machiavellego, obok Marksa - św. Augustyna. Nic dziwnego, że wielu stawiało jej zarzut, iż korzysta z tej tradycji zbyt lekko. $\mathrm{Na}$ obronę Arendt można powiedzieć, iż wcielała ona w czyn ten rodzaj filozofowania, o którym pisał Leo Strauss, gdy stwierdzał, że „filozofowanie polega (...) na rozmowie pomiędzy wielkimi filozofami czy też, mówiąc ogólniej, między wielkimi umysłami a nami”", sugerując jednocześnie, iż naszym zadaniem jest wywoływanie tej rozmowy. Hannah Arendt z pewnością tak właśnie czyniła.

Tradycja klasyczna w twórczości tej myślicielki zajmuje miejsce szczególne. Nie tylko ze względu na to, że jej pierwszy nauczyciel - Heidegger czerpał z niej bardzo dużo, co nieuchronnie wpłynęło na Arendt, lecz również dlatego, że po rozpoczęciu własnej intelektualnej drogi filozofowie klasyczni stale jej towarzyszyli. Jak stwierdził Paweł Śpiewak „Arendt jest (...) arcygrecka"s. Antyczna grecka polis stała się archetypem polityki dla Arendt; to w niej upatrywała ona najlepszego, a zapomnianego współcześnie sposobu działania politycznego oraz przeplatania się sfery publicznej i prywatnej. Kryzys współczesnych form uprawiania tej szlachetnej aktywności, jaką jest polityka, oraz zanik sensu tego pojęcia jako czegoś, co nie może być zastąpione ani poprzez sferę prywatną, ani przez społeczną, jest dla Arendt punktem wyjścia do poszukiwań filozoficznych i intelektualnych.

Szkic ten stawia sobie za zadanie nakreślenie współczesnego kryzysu, jaki dotyka to, co polityczne, na tle interpretacji dwóch znaczących w greckiej tradycji klasycznej postaci dokonanej przez Hannah Arendt. Wstępem do tych rozważań będzie analiza kondycji świata współczesnego ze szczególnym uwzględnieniem polityki, a zwłaszcza wskazanie kryzysów, które rodzą się na jej polu - umożliwi to poszukiwania źródeł, a być może i rozwiązań owych kryzysów u starożytnych. Zasadnicza część refleksji poświęcona będzie interpretacji dwóch filozofów: Sokratesa i Platona, dokonanej przez autorkę Kondycji ludzkiej. Wybór ten nie jest podyktowany faktem, iż są to myśliciele najbardziej znaczący w filozofii starożytnej, lecz raczej tym, że sposób rozumienia tych postaci przez Arendt prowadzi nas do zasadniczych problemów jej filozofii politycznej. Świadomie pominięty został tutaj trzeci

P. Śpiewak, Arendt: intensywność myślenia, w: H. Arendt, Między czasem minionym a przyszłym, przeł. M. Godyń, W. Madej, Warszawa 1994, s. 5.

4 L. Strauss, Czym jest edukacja liberalna?, przeł. Ł. Dominiak, „Dialogi Polityczne”, nr 7, 2007, s. 23.

P. Śpiewak, Arendt: intensywność myślenia..., s. 7. 
„wielki filozof" - Arystoteles, ponieważ jego interpretacja, choć ważna w myśli Arendt, w wybranej problematyce nie jest centralna.

\section{Kryzys współczesnej polityczności}

Zrozumienie owej zmiany, jaka dokonała się w nowożytności w odniesieniu do pojmowania człowieka, umożliwi diagnozę kryzysu współczesności. Według Hannah Arendt obecne życie ludzkie naznaczone jest piętnem chęci ucieczki „, ziemskiego więzienia"', uwolnienia się od kondycji ludzkiej. $\mathrm{Na}$ ową kondycję składają się specyficzne rodzaje działalności ludzi: vita activa oraz vita contemplativa, czy też - innymi słowy - aktywność oraz myślenie (w szerokim znaczeniu). Do składowych vita activa przynależą: praca (labor), będąca formą biologicznego utrzymania się przy życiu, stanowiącą również przejaw konieczności, jakiej jest podporządkowany człowiek; wytwarzanie (work), czyli „obłaskawianie” przyrody poprzez tworzenie świata sztucznych rzeczy ${ }^{7}$ oraz działanie (action), będące szczególnym rodzajem aktywności - jest ono bowiem par excellence polityczne, gdyż zachodzi pomiędzy ludźmi (a nie ludźmi i rzeczami jak wymienione powyżej), stanowiąc realizację ich wielości ${ }^{8}$. Do vita contemplativa należy za Arendt zaliczyć natomiast myślenie (w wąskim sensie), wolę oraz sądzenie ${ }^{9}$. Jak słusznie zauważa Mary G. Dietz, Arendt nie wyróżnia tutaj „empirycznych czy socjologicznych generalizacji” dotyczących tego, co ludzie robią, lecz konstruuje egzystencjalne kategorie mające wyróżnić człowieka od innych istot ${ }^{10}$.

Te dwa główne i powiązane ze sobą rodzaje aktywności, jakimi są vita activa i vita contemplativa, zostały rozerwane i powstała pomiędzy nimi prze-

H. Arendt, Kondycja ludzka, przeł. A. Łagodzka, Warszawa 2000, s. 6

Por. rozwiązanie tego problemu u J. Ortegi y Gasseta: „Człowiek z większą lub mniejszą aktywnością, oryginalnością i energią wytwarza świat, stale go produkuje i, jak widzieliśmy, świat lub wszechświat stanowi jedynie schemat czy interpretację, ową broń człowieka mającą zabezpieczać jego życie. Świat jest przeto narzędziem par excellence (...)" (J. Ortega y Gasset, Idea pokolenia, w: Tenże, Wokót Galileusza, przeł. E. Burska, Warszawa 1993, s. 26). Dla Arendt świat nie staje się narzędziem, lecz jest zapełniany rzeczami wytworzonymi przez narzędzia po to, by uczynić go stabilnym. Zgodne natomiast u obydwu autorów jest przekonanie, że taki świat ma stanowić ubezpieczenie egzystencji człowieka.

Por. szerzej H. Arendt, Kondycja ludzka..., s. 11-26.

9 H. Arendt, Myślenie, przeł. H. Buczyńska-Garewicz, Warszawa 2002, s. 109. Ostatnimi pracami Arendt były studia nad „życiem umysłu” jak nazwała cykl książek dotyczących podstawowych aktów życia umysłowego. Udało jej się napisać dwie z nich - Myślenie (On thinking) oraz Wolę (Willing), a prace nad trzecią dotyczącą władzy sądzenia przerwała śmierć autorki (do tej części zapisała jedynie motta).

10 M. G. Dietz, Hannah Arendt and Feminist Politics, w: Hannah Arendt. Critical Essays, L. P. Hinchman, S. K. Hinchman (ed.), New York 1994, s. 233. 
paść, która „od tamtej pory nigdy już nie została zasypana”"11. Aktywność myślowa została sprowadzona do refleksji, a więc działalności umysłowej pojawiającej się po tym, jak działanie zmieniło już świat, natomiast działanie „zostało skazane na przebywanie w pozbawionej sensu dziedzinie przypadku i ślepego losu"12.

Myślicielka, idąc tropem Greków, wskazuje również na istnienie dwóch sfer życia ludzkiego: sfery prywatnej i sfery publicznej. Każdej z nich przynależy inny rodzaj czynności - w sferze prywatnej dzieje się wszystko to, co podporząadkowane jest konieczności i utrzymaniu się przy życiu ${ }^{13}$, a więc przede wszystkim praca, natomiast sfera publiczna jest domeną wolności, gdzie ludzie jako istoty polityczne (zoon politikon) oraz władające mową (zoon logon echon ${ }^{14}$ ) mogą się sobie ukazywać poprzez działanie. Podobnie jest z równością - jak pisała Arendt w Korzeniach totalitaryzmu: „w przeciwieństwie do wszystkiego, co zawiera się w samym fakcie egzystencji, nie jest nam dana, lecz jest czynnikiem zorganizowania się ludzi” ${ }^{15}$, zatem „nie rodzimy się równi, stajemy się równi jako członkowie grupy na mocy naszej decyzji zagwarantowana sobie wzajemnie równych praw"16.

Prywatność była rozumiana deprywacyjnie - stanowiła w prawdzie podstawę ludzkiej egzystencji, ale ze względu na to, że nie wykraczała poza zwierzęcość, nie była również prawdziwie „ludzka”. To właśnie ona była sferą przemocy, władzy absolutnej i podporządkowania. Z racji tego, absurdalne wydawałoby się Grekom - według Arendt - porównanie, jakiego używa św. Tomasz pomiędzy władzą króla a władzą ojca w rodzinie, ponieważ są one zasadniczo odmienne i pochodzą z odmiennych sfer ${ }^{17}$.

11 H. Arendt, Sokrates, w: Taż, Polityka jako obietnica, przeł. W. Madej, M. Godyń, Warszawa 2007, s. 40.

12 Tamże.

13 Dlatego też kobiety - jako istoty z natury podporządkowane konieczności, choćby przez rodzenie i wychowanie dzieci - nie mogły przejawiać się w sferze politycznej. Nie był to wyraz czegoś, co nazwano by współcześnie dyskryminacją, lecz logiczną konsekwencją pojmowania troski o życie jako podporządkowania konieczności, która przeciwna jest sferze politycznej. Por. H. Arendt, Kondycja ludzka..., s. 33-44. O problemie płci u Greków N. Gładziuk, Omphalos czyli pępek świata. Płeć jako problem filozofii politycznej Greków, Warszawa 1997.

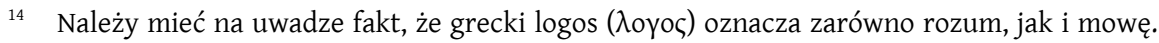
Określenie człowieka jako zoon logon echon można zatem interpretować dwojako - jako zwierzę posługujące się mową, ale i jako zwierzę posługujące się rozumem.

15 H. Arendt, Korzenie totalitaryzmu, t. I, przeł. M. Szawiel, D. Grynberg, Warszawa 1993, s. 336.

16 Tamże.

${ }_{17}$ Taż, Kondycja ludzka..., s. 33. U św. Tomasza czytamy dokładnie: „Kto więc rządzi społecznością doskonałą czyli miastem lub krajem, nazywa się królem; kto zaś rządzi domem, nie nazywa się królem, ale gospodarzem, nosi jednak jakieś podobieństwo króla, toteż niekiedy królów nazywa się ojcami ludu.” (św. Tomasz, O władzy, Ks. 1, 1. Co oznacza nazwa „król”, w: Tenże, Dzieła wybrane, przeł. J. Salij, Poznań 1984, s. 137). 
Jak zatem w tym kontekście wygląda współczesność? Hannah Arendt stanowczo twierdziła, że doświadczamy efektów przewrócenia rozumienia kondycji ludzkiej, jakie dokonało się na przestrzeni wieków. Prywatność ze sfery pogardzanej i ukrywanej wypłynęła na plan pierwszy, chroni się ją przed „zakusami” sfery publicznej i uważa za największe dobro. Przykładem błędnego pojmowania relacji pomiędzy tymi dwiema sferami jest liberalizm, a przede wszystkim jego błędne rozumienie wspólnoty politycznej.

Nowe pojęcie - tego, co społeczne, które pojawiło się najpierw u Cycerona (animal socialis), a potem u św. Tomasza (homo est naturaliter politicus, id est, socialis), zaburzyło równowagę pomiędzy dwiema podstawowymi sferami i wywarło zasadniczy wpływ na upadek polityczności. To, co społeczne nie jest bowiem ani prywatne, ani publiczne, lecz zawłaszcza obydwie te sfery. Współczesne społeczeństwo masowe to nic innego, jak „grupy społeczne (...) wchłonięte w społeczeństwo" ${ }^{18}$, jak „publiczna organizacja samego procesu życia" ${ }^{19}$ - czego oznaką jest skupienie się na pracy, która jest przecież aktywnością nakierowaną na podtrzymywanie życia. Zawłaszczenie tego, co publiczne doprowadziło do upadku polityki, jeśli rozumieć ją jako „domenę współistnienia i stowarzyszania się różnych ludzi”20. „Sfera publiczna straciła moc oświecania, która pierwotnie była częścią jej natury. Coraz więcej mieszkańców zachodniego świata, który od czasu upadku świata antycznego uważał prawo do apolityczności za jedną z podstawowych ludzkich swobód, robi z tego prawa użytek, wycofując się ze świata i porzucając swoje obowiązki publiczne" ${ }^{21}$. Zniknął gdzieś sposób zdobywania sobie nieśmiertelności przez dzielność w sferze publicznej, zniknęły też cnoty (aretai), które mogły się ujawniać tylko wśród innych. Nie można już dłużej mówić o dziedzinie sfery publicznej jako rzeczy wspólnej (res publica).

Deprecjacja sfery publicznej i jej stopniowe zawłaszczanie przez prywatność doprowadziły również do przeniesienia do polityki działań charakterystycznych dla tego, co przeciwne publicznemu. Przemoc, zwłaszcza ta wykorzystana w systemach totalitarnych, przynależy przecież do działań o charakterze przedpolitycznym. Ruchy totalitarne nie tylko stanowiły apogeum wtargnięcia prywatności do sfery publicznej, lecz doprowadziły do masowego posłuszeństwa wobec machiny biurokratycznej ${ }^{22}$ i zakwestiono-

18 H. Arendt, Kondycja ludzka..., s. 47. Co ciekawe, Arendt łączy upadek rodziny z pojawieniem się społeczeństwa, sugerując, że to społeczeństwo wchłonęło wspólnotę rodzinną i doprowadziło do jej zniszczenia.

19 Tamże, s. 52.

20 Taż, Wprowadzenie w politykę, w: Taż, Polityka jako obietnica..., s. 124.

21 Taż, Man in Dark Times, New York 1983, s. 4-5.

22 Arendt poddała jeden $\mathrm{z}$ takich przypadków szczegółowej analizie - była korespondentką pisma „New Yorker” w czasie procesu Adolfa Eichmanna, który odbył się w Jerozolimie w 
wania podstawowych zasad moralnych. Zjawisko to było według Arendt efektem zaprzestania myślenia i samodzielnego dokonywania sądów, których warunkiem wstępnym „nie jest wysoka inteligencja czy dogłębna znajomość kwestii moralnych"23, lecz pewnego rodzaju dyspozycja do dokonania takiego wysiłku. Utrata zdolności do myślenia, czyli bezgłośnego „dialogu mnie samej z moim «ja»" ${ }^{4}$, otwiera możliwość przymknięcia oczu na zło czy, mówiąc ściślej, jego nieświadomości.

Wskazane problemy oraz rosnąca technicyzacja i atomizacja społeczeństwa prowadzą do pytania, czy czasem nie byłoby dla nas lepiej, „gdybyśmy całkiem się pozbyli polityki i działania politycznego i zastąpili je przez zwyczajne "zarządzanie rzeczami»" ${ }^{25}$, czyli przez efektywną i niezawodną weberowską biurokrację. Arendt z pewnością odpowiedziałaby tutaj przecząco, a jej filozofia wydaje się próbą ocalenia sensu polityki we współczesnym świecie, który uczynił wiele, aby ją wyplenić i zastąpić czymś, co ją tylko udaje.

\section{Sokrates: filozof $\mathrm{w}$ polis}

„Problem Sokratesa”, jak nazwał kwestie związane z tym greckim filozofem Fryderyk Nietzsche ${ }^{26}$, jest dla Arendt problemem wielopłaszczyznowym. Łączą się w jego osobie dwa zasadnicze konflikty o szczególnym znaczeniu dla filozofii polityki, a zwłaszcza dla filozofii Arendt. Przede wszystkim Sokrates uosabia napięcie, jakie powstaje pomiędzy filozofem a polis. Konflikt ów - pomiędzy byciem dobrym obywatelem a byciem filozofem - nie odstępuje filozofii na krok od czasu jej powstania i stanowi przedmiot nieustannej refleksji ${ }^{27}$. Idąc za wskazówką Arystotelesa, który za-

1961 roku, a swoje spostrzeżenia o „banalności zła” spisała w wydanej po raz pierwszy w 1963 roku książce Eichmann in Jerusalem. A Report on the Banality of Evil (Polskie wydanie: Eichmann w Jerozolimie. Rzecz o banalności zła, przeł. A. Szostkiewicz, Kraków 1987, 1998, 2004).

23 H. Arendt, Odpowiedzialność osobista $w$ warunkach dyktatury, w: Taż, Odpowiedzialność i władza sadzenia, przeł. W. Madej, M. Godyń, Warszawa 2007, s. 75.

24 Taż, Kilka zagadnień filozofii moralnej, w: Taż, Odpowiedzialność $i$ władza sądzenia..., s. 122.

25 J. Kohn, Wprowadzenie, w: H. Arendt, Polityka jako obietnica..., s. 9.

26 F. Nietzsche, Problem Sokratesa, w: Tenże, Zmierzch bożyszcz, przeł. P. Pieniążek, Kraków 2006, s. 13-18. Należy jednakże wskazać, że stosunek Nietzschego do Sokratesa był skrajnie negatywny. Sokrates dla tego niemieckiego myśliciela „był motłochem”; zdawał się być lekarzem i uzdrowicielem, ale był symbolem upadku Aten, bowiem uosabiał instynkty pseudogreckie.

27 Ów nieuchronny konflikt doprowadził według Leo Straussa do pojawienia się pisarstwa ezoterycznego u filozofów, które kryjąc prawdziwe ich myśli i dając się rozszyfrować jedynie nielicznym zdolnym do przekroczenia tej bariery, jednocześnie chroni samego filozofa. Jak pisze sam Strauss: ,prześladowanie powoduje więc powstanie szczególnego typu techniki pisania, a tym samym szczególnego typu literatury, w którym prawda o wszystkich 
uważył, iż jedynie w państwie idealnym mamy do czynienia z ontologicznym utożsamieniem Dobra oraz dobra państwa, a „dobry obywatel” i „dobry człowiek" znaczą dokładnie to samo ${ }^{28}$, możemy stwierdzić, że filozof ze swym pragnieniem dążenia do prawdy jest predestynowany do bycia nieposłusznym wobec polis. Drugim konfliktem, który jest - w pewnym ograniczonym sensie - wersją konfliktu filozofa z polis, jest konflikt pomiędzy myśleniem a działaniem.

Nie zrozumiemy śmierci Sokratesa, jeśli nie odpowiemy na pytanie, czy stanowił on dla polis takie zagrożenie, że koniecznością było jego zgładzenie $^{29}$. Według Arendt filozofia, czyli dążenie do prawdy niezależnej od świata spraw ludzkich, „odciągała swoich wyznawców od dziedziny dobra wspólnego i sprawiała, że polis nie miała z nich żadnego pożytku" ${ }^{30}$. Niemożliwe jest aktywne uczestnictwo $\mathrm{w}$ życiu politycznym polis oraz zajmowanie się filozofią, ponieważ akty umysłowe nie mają natury fenomenalnej, a zatem nie mogą przejawiać się w sferze publicznej. Mogą one zaistnieć wyłącznie „przez zdecydowane wycofanie się ze świata zjawisk”"11 a to wycofanie jest ich podstawowym warunkiem wstępnym. Jedynym przejawem myślenia $\mathrm{w}$ świecie zewnętrznym jest roztargnienie ${ }^{32}$. W tym kontekście epikurejskie lathe biosas (żyj w ukryciu) może być rozumiane właśnie jako określenie tego podstawowego warunku myślenia - samotności. Samotność zatem to egzystencjalny stan, w którym „sam sobie dotrzymuję towarzystwa"33, różny od osamotnienia, podczas którego nikt mi - nawet ja - nie towarzyszy. Tak określona samotność jest zasadniczo różna od działania,

istotnych sprawach jest przedstawiana między wierszami" (L. Strauss, Prześladowanie i sztuka pisania, w: Tenże, Sokratejskie pytania..., s. 110).

28 Por. Arystoteles, Polityka, 1276b-1277a, przeł. L. Piotrowicz, w: Tenże, Dzieła wszystkie, t. VI, Warszawa 2001, s. 80-81.

29 Jak zauważył Dariusz Karłowicz: „Kiedy w połowie II wieku chrześcijanie szukać będa właściwego słowa na określenie męczennika, użyją terminu świadek (martys). Cokolwiek sądzić o powodach tej decyzji, był to wybór czytelny dla wszystkich, którzy wychowali się na metaforze jaskini oraz legendzie procesu Sokratesa. Kim jest mędrzec, jeśli nie świadkiem zdającym sprawę z tego, co widział na własne oczy?" (D. Karłowicz, Arcyparadoks śmierci. Męczeństwo jako kategoria filozoficzna - pytanie o dowodowa wartość męczeństwa, Kraków 2000, s. 9).

30 H. Arendt, Sokrates..., s. 44

31 Taż, Myślenie..., s. 117.

32 Książka zawierająca spisane myśli, jest rezultatem procesu wytwarzania, a jedynie pośrednio procesu myślenia, ponieważ, aby móc przemienić ulotność myśli w coś stałego, musimy według Arendt jednocześnie przestać myśleć w tym momencie.

33 H. Arendt, Myślenie..., s. 115. 
które zmierza do tego, by być widziane ${ }^{34}$; „niech nas widzą w działaniu” jak mówił John Adams ${ }^{35}$.

Jednakże, czy samo odosobnienie filozofa jest faktycznie tym, co polis boli najbardziej? Wydaje się, że nie. Thomas Pangle, charakteryzując zawarte w Chmurach podejście Arystofanesa do filozofii, zauważa, że „,naukowe lub filozoficzne przedsięwzięcie jest z konieczności destrukcyjne w stosunku przywiązań, które są szańcem zdrowej republiki" ${ }^{\prime 36}$. Życie w polis wymaga przestrzegania pewnych oczywistych reguł i zasad ${ }^{37}$. Słowo „oczywistych” jest tutaj kluczem do zrozumienia problemu Sokratesa. Podważanie oczywistości, jakiego dopuszcza się filozof, jest immanentnie zawarte w samym akcie myślenia - nieustanne kwestionowanie osiągniętych wyników, „nawyk rozważania wszystkiego, co się zdarza i co zwraca uwagę" ${ }^{38}$ nie pozwala na przyjmowanie podawanych „oczywistości” bezrefleksyjnie. Skoro, jak sugeruje Micheal Oakeshott, filozofia to "nieskrępowany refleksyjny impuls" ${ }^{39}$, "zaproszenie do radykalnego burzycielstwa"40, to przekonanie o niekwestionowalności pewnych założeń jest czymś, co filozofię zabija.

Sokrates z pewnością był $\mathrm{w}$ takim rozumieniu filozofem par excellence. Kwestionuje „oczywiste” rozumienia dzielności (Menon), pobożności (Eutyfron), sprawiedliwości (Państwo) i miłości (Uczta). Jego zaangażowanie w „milczący dialog pomiędzy mną a moim «ja»" ${ }^{41}$, prowadzi do tego, że w platońskim Gorgiaszu stwierdza on, że „wolałbym, niechby mi raczej lira

$34 \quad$ Szczególnym przypadkiem niewidzialności działania jest czynienie dobra. Tak według Arendt należałoby rozumieć słowa Jezusa z Ewangelii według św. Mateusza: „niech nie wie lewa twoja ręka, co czyni prawa" (Mt 6,3), bowiem świadomość bycia dobrym i czynienia dobra niszczy ową dobroć. Zob. szerzej H. Arendt, Kondycja ludzka, R. 10. Umiejscowienie ludzkich czynności, s. 81-86 oraz Mt 6,1.

35 H. Arendt, Myślenie..., s. 112.

36 T. Pangle, Socrates on the Problem of Political Science Education, „Political Theory”, vol. 13, no. 1, 1985, s. 114 [tłum. własne]. Autor w dalszej części swej rozprawy poświęconej analizie pseudoplatońskiego dialogu Teages podnosi problem przydatności wiedzy filozofa dla polis, a konkretnie dla poszczególnych jego obywateli: „Wcześniej czy później w połowie zdeprawowani obywatele (...) odszukają Sokratesa z powodu władzy, która - jak czują - mogłaby być ich, gdyby oni lub ich synowie nauczyli się, jak wyzyskać to, co wie filozof" (Tamże, s. 115).

37 Leo Strauss podtrzymując pogląd, że filozof kwestionuje oczywistości, a więc tradycję, zauważa, że „nie można rozumnie utożsamiać dobra z tym, co odziedziczone, jeśli się nie przyjmie, że przodkowie byli absolutnie lepsi od «nas», to znaczy, że byli lepsi od wszystkich zwykłych śmiertelników" (L. Strauss, Prawo naturalne w świetle historii, przeł. T. Górski, Warszawa 1969, s. 81).

38 H. Arendt, Myślenie..., s. 38.

39 M. Oakeshott, Filozofia polityki, w: Współczesna filozofia polityki, D. Pietrzyk-Reeves, B. Szlachta (red.), Kraków 2003, s. 79.

40 Tamże, s. 80

${ }^{41}$ H. Arendt, Odpowiedzialność osobista w warunkach dyktatury..., s. 75. 
była niestrojna i fałszywie brzmiała, niechby tam chór, któremu bym przodował, niechby się ze mną większość ludzi nie zgadzała, a twierdziła przeciwnie niż ja, aniżeliby ja sam, jedną jednostką będąc, miał nosić w sobie rozdźwięk wewnętrzny i sprzeczne myśli wygłaszać" ${ }^{42}$. Myślenie wymaga zgody z samym sobą, wyklucza dopuszczanie się zła, po którym może nam zabraknąć w nas samych partnera do rozmowy. Nie zważa również na obiegowe opinie i przesądy, lecz kwestie, które poruszają, podnosi na nowo.

Sokrates nie uważał się jednakże za posiadacza mądrości, a słowa wyroczni uznał początkowo za żart. Nie chował się również przed innymi obywatelami, więcej nawet - wychodził im naprzeciw. Dla niego doxa było tym, co dokei moi - tym, co mi się ukazuje, a opinia była formą wyrażenia tego, jak odkrywa się przed nami świat. Jak pisze Arendt, „doksa nie była więc ani subiektywnym widzimisię, ani też prawdą absolutną"43, ponieważ świat przed każdym otwiera się w inny sposób ${ }^{44}$. Metoda położnicza Sokratesa opierała się na dwóch założeniach wypływających z takiego rozumienia opinii. Przede wszystkim Sokrates musiał poznać „okno na świat" ${ }^{45}$, doxa swojego rozmówcy. Po wtóre, z racji tego, że nikt nie może znać prawdy ukrytej w jego własnej opinii, Sokrates pomagał wydobyć prawdę na światło dzienne. Arendt uważa, że taka prawda „nie oznaczała zniszczenia opinii, przeciwnie - polegała na odsłonięciu doksa w jej własnej prawdziwości" ${ }^{46}$. Jednak stwierdza również, że takie poszukiwania mogą mieć katastrofalne skutki - „doksa albo zostaje całkowicie zniszczona, albo to, co się w niej «jawi», okazuje się złudzeniem" ${ }^{47}$. Rozwiązaniem tej sprzeczności może być wyróżnienie dwóch poziomów rozumienia doxa u Arendt. Analizując je na poziomie epistemologicznym jako poznawcze mniemania, opinie i sądy poszczególnej osoby, można stwierdzić, że faktycznie są one podatne na zniszczenie $\mathrm{w}$ trakcie rozmowy z Sokratesem. Jednak na poziomie ontologicznym, jak uważa Arendt, $u$ Sokratesa nie ma przeciwstawienia prawdy i opinii jako dialektycznej pary prawdy i nie-prawdy czy raczej bytu i nie-bytu. Opinia zatem posiada własne istnienie, nie jest jedynie bladym odbiciem idealnej prawdy.

Dopiero teraz uświadamiamy sobie jak daleko odszedł Platon od sokratejskiego rozumienia prawdy i opinii, gdy je sobie przeciwstawił. Związek pomiędzy filozofią i działalnością na forum publicznym stał się możliwy

Platon, Gorgiasz, 482 b-c, w: Tenże, Gorgiasz, Menon, przeł. W. Witwicki, Kęty 2002.

43 H. Arendt, Sokrates..., s. 47.

${ }^{44}$ Obiektywność świata została zachowana, ponieważ mimo jego odmiennego ukazywania się, był on nadal jeden.

45 H. Arendt, Sokrates..., s. 48.

${ }^{46}$ Tamże, s. 49.

47 Tamże, s. 58 
w osobie Sokratesa, chociaż zapłacono za niego wysoką cenę. Proces filozofa - jak zauważa Dariusz Karłowicz - jest efektem „zderzenia zawsze dziwnej, niepokojącej prawdy z codziennością mniemań i dóbr pozornych" ${ }^{48}$. Wraz z osądzeniem i skazaniem Sokratesa „przepaść pomiędzy filozofią a polityką otworzyła się" ${ }^{\prime \prime}$, a rezultatem jego śmierci było narodzenie się tradycji myśli politycznej zapoczątkowanej przez Platona.

\section{Platon: „pęknięta nić tradycji”}

Leo Strauss stwierdził, iż w zasadzie „można powiedzieć, że dialogi Platona jako całość są w większym stopniu pomnikiem na cześć życia Sokratesa niż przedstawieniem jego nauczania" ${ }^{50}$. Mimo pewnej przesady tego stwierdzenia, nie da się ukryć, że osoba Sokratesa miała dla Platona i jego filozofii znaczenie kluczowe. $Z$ tezą tą zgadza się również Hannah Arendt, jednakże związki pomiędzy obydwoma filozofami rozpatruje nieco inaczej niż jest to przeważnie czynione. Sokrates swoją działalnością na forum publicznym udowodnił, że filozofia i polityka nie muszą być w niezgodzie. Filozof ma pobudzać obywateli do myślenia, nękać ich pytaniami i wydobywać $\mathrm{z}$ nich prawdę - jakże to dalekie od bezpiecznego wycofania $\mathrm{z}$ forum!

W chwili, gdy filozof „odwraca się od polityki, a następnie powraca do niej $^{51}$, aby narzucić swoje normy sprawom politycznym" ${ }^{52}$, gdy niczym szekspirowski Prospero zamierza naprawić ludzkie błędy swoją różdżką ${ }^{53}$, rozpoczyna się tradycja filozofii politycznej. Moment tej przemiany dokonuje się, gdy „w alegorii jaskini z Państwa Platon opisał sferę spraw ludzkich (...) w kategoriach ciemności, zamętu i ułudy"54, a nie, jak to było wcześniej u Greków, jako sferę jasności, cnoty i dzielności, które ujawniały się w rywalizacji najlepszych na forum publicznym. „Dopiero u Platona zajmowanie się tym, co wieczne, i życie filozofa postrzegane są jako sprzeczne i popadające w konflikt z dążeniem do nieśmiertelności" ${ }^{55}$.

48 D. Karłowicz, Arcyparadoks śmierci..., s. 31.

H. Arendt, Sokrates..., s. 40

50 L. Strauss, Plato, w: History of Political Philosophy, L. Strauss, J. Cropsey (ed.), Chicago 1987, s. 7.

51 Zob. interpretację pojawiającej się na początku Państwa Platona drogi w górę (do Aten) i drogi w dół (do Pireusu) dokonaną przez E. Voegelina: E. Voegelin, Platoński ład duszy, przeł. H. Krzeczkowski, „Znak”, nr 9/10, 1985, s. 147-165; E. Voegelin, Order and History, t. III Plato and Aristotle, Baton Rouge1977, s. 52-70.

52 H. Arendt, Tradycja a epoka nowożytna, w: Taż, Między czasem minionym a przyszłym..., s. 29.

53 Zob. W. Shakespeare, Burza, dowolne wydanie i tłumaczenie.

54 H. Arendt, Tradycja a epoka nowożytna..., s. 29.

55 Taż, Kondycja ludzka..., s. 25. 
Wczesnogreckie rozumienie relacji pomiędzy vita activa i vita contemplativa, między tym, co prywatne, a tym, co publiczne, uległo u Platona zasadniczemu odwróceniu. Platoński projekt państwa zrodził się według Wernera Jaegera z problemu sprawiedliwości - „dla kogoś, kto był uczniem Sokratesa, sprawiedliwość nie mogła być identyczna z posłuszeństwem wobec prawa (...). Platońskie pojmowanie sprawiedliwości przechodzi do porządku nad wszystkim, co jest w niej tworem wyłącznie ludzkim, szukając jej źródeł w samej duszy człowieka, ponieważ to, co filozof może nazwać sprawiedliwym, musi mieć swoją podstawę w tejże duszy" ${ }^{16}$. Sprawiedliwość polis zawiodła, a opinie i sądy ateńskich obywateli doprowadziły do śmierci Sokratesa. Według Arendt zapalczywość, z jaką Platon „piętnował opinię” ${ }^{57}$, stanowi kamień węgielny koncepcji prawdy jako czegoś przeciwnego opinii i jego poszukiwań czegoś absolutnego i niezależnego od przypadkowych mniemań obywateli ateńskich. Filozoficzna teoria idei nie stanowi zatem teorii „mierników i wzorców, lecz jej źródła miały charakter polityczny” 58 .

Wspólna nam tradycja myśli politycznej „wzięła swój początek od odkrycia Platona, że w doświadczeniu filozoficznym w pewien sposób zawarte jest odwrócenie od wspólnego świata spraw ludzkich" ${ }^{59}$. Gdzie jednak leży jej koniec? Według Arendt „kres nadszedł, gdy filozof odwrócił się od filozofii, aby «urzeczywistnić» ją w polityce" ${ }^{60}$. Biorąc pod uwagę relacje tego, co prywatne, społeczne i publiczne, łatwiej zrozumieć fakt, że dla Arendt myślicielem, który doprowadził ową platońską tradycję do końca, był Marks. Marks postawił tradycyjną, to znaczy przedkładającą myślenie nad działanie, kontemplację nad pracę i filozofię nad politykę, hierarchię „na głowie”.

Zapowiedzią owego kresu był jego platoński początek. Przepowiednie o tym, że „państwo obumrze”, a praca zniesie samą siebie, tkwią swymi korzeniami w Państwie Platona. Karl R. Popper poddając surowej krytyce Państwo Platona w dziele Społeczeństwo otwarte i jego wrogowie, stawia tezę, że tego greckiego filozofa można uznać za prekursora totalitaryzmu ze względu na pewne aspekty jego myśli ${ }^{61}$. Rekonstruując podejście Arendt do tej

56 W. Jaeger, Paideia, przeł. M. Plezia, H. Bednarek, Warszawa 2001, s. 772. Myśl Platona została poddana dość szczegółowej analizie - Zob. szerzej Księga trzecia. Epoka wielkich wychowawców i systemów wychowawczych, s. 507-1202.

57 H. Arendt, Sokrates..., s. 41.

58 Tamże, s. 42.

59 Taż, Tradycja a epoka nowożytna..., s. 37.

60 Tamże, s. 29.

61 Popper wymienia tutaj zwłaszcza a) „ścisły podział klasowy”, b) „utożsamienie losu państwa z losem klasy rządzącej”, c) „monopol klasy rządzącej na wykształcenie wojskowe; prawo noszenia broni i prawo do wszechstronnego wykształcenia; zakaz uczestniczenia $\mathrm{w}$ jakichkolwiek działaniach o charakterze ekonomicznym, a przede wszystkim zakaz zarabiania na życie”, d) „stała i surowa cenzura wszelkiej aktywności intelektualnej w łonie 
kwestii, Nina Gładziuk zauważa, że chociaż - podobnie jak Popper - Arendt jest sceptyczna w stosunku do Platona, to jednak nie idzie w swoim osądzie tak daleko ${ }^{62}$. Zauważa nawet, kładąc nacisk na indywidualną odpowiedzialność, że ,jeśli ktoś wywodzi czyny Hitlera od Platona, Joachima da Fiore ${ }^{63}$, Hegla lub Nietzschego, z nauki nowożytnej i techniki czy nihilizmu rewolucji francuskiej, wszystko jest w porządku. Ale kiedy ktoś nazwie Hitlera ludobójcą (...), wszyscy zgodnie twierdzą, że taki osąd jest prymitywny, że brak mu głębi i nie powinien ingerować w interpretację Historii” ${ }^{64}$. Różnica w ocenie polega na tym, że platońskie społeczeństwo to według niemieckiej myślicielki społeczeństwo maksymalnie uspołecznione, wchłonięte przez oikos, a nie przez państwo - choćby przykładowe wspólne spożywanie posiłków w Państwie to efekt zawłaszczenia sfery publicznej przez czynności prywatne, a nie aneksja prywatności przez to, co publiczne ${ }^{65}$. Marksowski „człowiek uspołeczniony” jest zatem kontynuacją tradycji platońskiej i jednocześnie jej zniszczeniem.

Arendt uważała, że myśl Marksa można zrozumieć tylko, jeśli będzie się miało na uwadze jego buntowniczą postawę w stosunku do tradycji. I tak, kiedy Marks powiedział, że „praca stworzyła człowieka”, to oznaczało to jednocześnie, że nie zrobił tego Bóg; gdy stwierdził, że przemoc jest akuszerką dziejów, to jednocześnie przeczył tradycji, w której była ona ostatecznością; gdy utożsamiał działanie z przemocą, kwestionował arystotelesowską koncepcję człowieka jako zoon politikon; gdy chciał urzeczywistniać filozofię, sprzeciwiał się postrzeganiu jej jako czegoś poza-światowego ${ }^{66}$. Jedność myślenia i działania została ostatecznie rozerwana i, jak zauważył Marcin Król, „jednostkom pozostały dwa uczciwe wyjścia - poświęcić się tylko myśleniu lub tylko działaniu"67.

Tradycja nie tyle znajduje się w kryzysie, jak określa to wielu innych myślicieli, ile „zachowuje głuche milczenie, ilekroć staje wobec autentycz-

klasy rządzącej oraz ciągła działalność propagandowa, mająca na celu urobienie i ujednolicenie umysłów. Zakaz i uniemożliwianie wprowadzania jakichkolwiek innowacji w zakresie wychowania, prawodawstwa i religii”, e) „samowystarczalność państwa; państwo musi dążyć do ekonomicznej autarkii” (K. R. Popper, Społeczeństwo otwarte i jego wrogowie, przeł. H. Krahelska, t. I, Warszawa 1993, s. 108-109).

62 N. Gładziuk, Cóż po Grekach? Archetyp polis w twórczości Hannah Arendt, Warszawa 1991, s. 65-69.

${ }^{63}$ To może być pewien przytyk do E. Voegelina, który właśnie w Joachimie z Fiore upatrywał źródła nowożytności. Por. E. Voegelin, Nowa nauka polityki..., s. 106-115.

${ }_{64}$ H. Arendt, Odpowiedzialność osobista $w$ warunkach dyktatury..., s. 54.

65 Por. „A będą się stołowali we wspólnym lokalu, jak na wyprawie wojennej, i będą żyli wspólnie", Platon, Państwo, 416e, przeł. W. Witwicki, Kęty 2003, s. 115.

66 H. Arendt, Tradycja a epoka nowożytna..., s. 33-36.

67 M. Król, Hannah Arendt, w: H. Arendt, Myślenie..., s. 10. 
nych problemów współczesności" ${ }^{68}$. Nie znajdziemy w niej odpowiedzi na problem totalitaryzmu czy rewolucji, które tak interesowały Arendt. „Bez tradycji - która dokonuje wyboru i nazywa, która przechowuje i konserwuje, która wskazuje, gdzie są skarby i na czym polega ich wartość - ciągłość czasu nie istnieje, nie ma też - biorąc rzecz w ludzkim wymiarze - przeszłości ani przyszłości, tylko odwieczna przemiana świata i biologiczny cykl żyjących w nim istot" ${ }^{69}$. Działanie i myślenie we współczesnym świecie nieuchronnie musi w takim razie zaczynać od początku - „trzeba myśleć tak, jakby nikt nigdy nie myślał przed nami, i dopiero potem zacząć się uczyć od innych"70. Tkwi w tym ogromna szansa dla współczesnego świata, szansa zbudowana w prawdzie na upadku tradycji, lecz otwierająca przed światem nowe możliwości. To właśnie myślenie może być tą szansą.

\section{Podsumowanie}

Dokonana przez Hannah Arendt interpretacja Sokratesa i Platona oparta na szerokiej znajomości tradycji klasycznej zmierza w dwóch kierunkach. Inspiracje klasyczne służą zarówno diagnozie sytuacji współczesnego świata, jak i stanowią próbę odbudowania szlachetnego rozumienia polityki, co może się dokonać jedynie przez nadanie działaniu i myśleniu odpowiedniego znaczenia. Powrót do antycznych źródeł umożliwia zrozumienie procesów, jakie dokonały się w historii i które doprowadziły do obecnego stanu - kryzysu - polityczności. Linia łącząca Platona i Marksa jest dla Arendt aż nadto wyraźna, a poszukiwanie klucza do zrozumienia dziejów myśli politycznej jest $u$ niej uwieńczone sukcesem - to przemiany pojmowania vita activa i vita contemplativa oraz ich wzajemnej relacji tłumaczą zasadnicze zmiany w myśli i świecie.

Drugim kierunkiem interpretacji jest próba znalezienia u starożytnych wskazówek do udzielenia odpowiedzi na dręczące współczesność problemy. Nie są to jednakże odpowiedzi na pytania, jakie stawia przed nami czas obecny, ponieważ tradycja wobec zasadniczej nowości i odmienności współczesnych czasów nie jest w stanie nic na ten temat powiedzieć, lecz właśnie wskazówki - przydatne do własnego przemyślenia miejsca człowieka w świecie. Arendt „nie miała zamiaru (...) związywać i sztukować” ${ }^{71}$ zerwanej nici tradycji, ponieważ jest to niemożliwe z jej punktu widzenia. Nie oznacza

H. Arendt, Tradycja myśli politycznej, w: Taż, Polityka jako obietnica..., s. 72.

69 Taż, Między czasem minionym a przyszłym, w: Taż, Między czasem minionym a przyszłym..., s. 17.

70 Taż, The Recovery of the Public Word, New York 1979, s. 337, cyt. za: M. Król, Hannah Arendt..., s. $14-15$.

71 M. Król, Hannah Arendt..., s. 22. 
to dla niej bynajmniej, że nie należy korzystać z bogatego dorobku filozofii i szukać tam inspiracji. Arendt jest jak najdalsza od takiego rozwiązania.

„Odkryte przez Greków doświadczenie polityczności posiadało moc objawiająca nowy naówczas wymiar ludzkiej kondycji"72 - o tym doświadczeniu wpisanym w kondycję ludzką współczesność zdała się zapomnieć. Hannah Arendt dąży do odbudowy właściwego rozumienia polityki, korzystając w dużym stopniu z polityczności greckiej polis. Antyczny agon zjawiania się na forum publicznym ujawnia się w kontraście do wchłoniętych przez prywatność większości dzisiejszych obywateli.

Próba odbudowy tego, co polityczne, zbliża nieuchronnie Arendt do innego filozofa niemieckojęzycznego - Carla Schmitta. Dla Schmitta polityczność związana jest $\mathrm{z}$ radykalnym i egzystencjalnym odróżnieniem wroga od przyjaciela ${ }^{73}$. Nie istnieją kwestie ściśle „polityczne”, lecz mogą się one takimi stać, jeśli dany problem stanie się na tyle ważny, że zaangażuje jednostki na poziomie zasadniczego odróżnienia wróg-przyjaciel. Ten relacyjny aspekt polityki został uwydatniony w używaniu przez Schmitta raczej przymiotnika „polityczny” niż rzeczownika „polityka”, który mógłby być rozumiany zbyt substancjalnie ${ }^{74}$. W przeciwieństwie do Schmitta, który określa polityczność raczej ze względu na formę, Arendt analizuje ją „treściowo” uważa przeniesienie w sferę publiczną działań, które związane są z koniecznością, za zburzenie polityczności - nie wszystkie kwestie zatem powinny stać się politycznymi, niektóre powinny pozostać w ukryciu oikos.

Drogą wyjścia ze ślepej uliczki, w którą zapędziły świat współczesny totalitaryzmy czy broń atomowa, wydaje się sokratejsko-platońskie rozumienie myślenia. W prawdzie „potrzeba myślenia (...) nie pozostawia po sobie niczego tak dotykalnego ani też nie osiąga spełnienia" ${ }^{\text {", }}$, jednak według Arendt odpowiedź na pytanie o to, „czy z tak bezowocnej aktywności może w ogóle wyniknąć coś istotnego dla świata, w którym żyjemy"76 jest pozytywna. Stawia tezę, że myślenie może być lekarstwem - czy raczej szczepionką - na zło.

72 P. Śpiewak, W stronę wspólnego dobra, Warszawa 1998, s. 130.

73 C. Schmitt, Pojęcie polityczności, w: Tenże, Teologia polityczna i inne pisma, przeł. M. Cichocki, Kraków 2000, s. 197 i nn. „Chcąc określić pojęcie polityczności, trzeba wpierw ustalić i opisać specyficzne, polityczne kategorie. (...) Specyficznie polityczne rozróżnienie, do którego można sprowadzić wszystkie polityczne działania i motywy, to rozróżnienie przyjaciela i wroga" (Tamże, s. 197-198).

74 C. E. Frye, Carl Schmitt's Concept of the Political, „The Journal of Politics”, vol. 28, no. 4, 1966, s. 821.

75 H. Arendt, Myślenie a sady moralne, w: Taż, Odpowiedzialność i władza sądzenia..., s. 192.

76 Tamże, s. 197. 
Bogactwo odniesień do myślicieli nowożytnych nie pozwala ustawić Hannah Arendt w jednym szeregu z piewcami klasyczności (będącymi nierzadko potępicielami nowożytności). Arendt docenia nowożytność, choć widzi jej błędy i potknięcia. W poszukiwaniu recepty na odrodzenie polityki zwraca się ku myśli klasycznej - jednak pisma Platona czy Arystotelesa są dla niej tylko wstępem, od Monteskiusza, Marksa czy Machiavellego uczy się co najmniej tyle, co od starożytnych. Stwierdzenie Arendt, że „nie wiem, co wniosłam do cywilizacji europejskiej, ale przyznaję, że trzymałam się europejskiego dziedzictwa w wielką determinacją" ${ }^{\prime 7}$, jest zatem najlepszym podsumowaniem stosunku myślicielki do tradycji - nie tylko klasycznej - myśli politycznej.

K I N G A M A R U L E W S K A

77 H. Arendt, Prolog, w: Taż, Odpowiedzialność $i$ władza sądzenia..., s. 37. Słowa te wypowiedziała na gali z okazji przyznania jej Sonning Prize w 1975 roku. 


\section{The classical tradition and modern crisis of „the political" in the thought of Hannah Arendt}

The main purpose of this essay is to explicate the selected issues of the political philosophy of Hannah Arendt - a Jewish-German-American theorist, well-known for her analysis of the roots of the totalitarianism. Arendt's diagnosis of the modern world's crisis, which encompasses also "the political", works on the assumption that the classical tradition is essential for adequate comprehension of the contemporary controversies. The article constitutes an interpretation of Socrates' and Plato's works, accomplished by the author of The Human Condition.

A further interpretation of the philosophers' works is preceded by the comments on Arendt's vision of contemporary world's condition, with special focus on politics and particularly on its crisis, necessary for searching the origins of the controversies the philosophy is being faced with and, presumably, the answers for them. The fundamental part of the essay is a reflection on Arendt's interpretation of the mentioned philosophers' thought.

In Arendt's thought, Socrates personifies the tension between philosopher and polis, but also between vita activa and vita contemplativa. Contrary to Socrates, considered by Arendt as the only person able to perfectly combine these two fundamental aspects of human life, the conception of Plato is a foundation stone for their division; his trauma caused by the trial of Socrates resulted in preference of vita activa - the life of a philosopher who strives for the truth comprehended as an antithesis of opinion. The tradition of Western political thought came from Plato and ended with Karl Marx.

Based on the expertise in classical tradition, Hannah Arendt in her interpretation of classical tradition had two aims: to diagnose properly the situation of modern world and to rebuild the noble understanding of politics through the classical categories. 